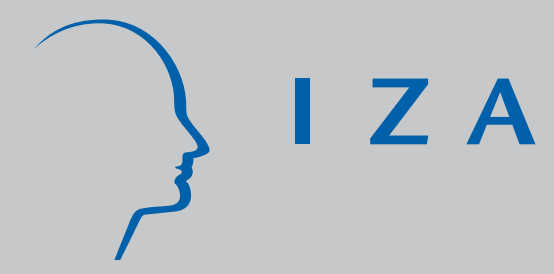

IZA DP No. 2555

Minimum Wages, Minimum Labour Costs and the Tax Treatment of Low-Wage Employment

Herwig Immervoll

J anuary 2007 


\title{
Minimum Wages, Minimum Labour Costs and the Tax Treatment of Low-Wage Employment
}

\author{
Herwig Immervoll \\ OECD, ISER, University of ESSex, \\ European Centre Vienna and IZA
}

\author{
Discussion Paper No. 2555 \\ January 2007
}

IZA

P.O. Box 7240

53072 Bonn

Germany

Phone: +49-228-3894-0

Fax: +49-228-3894-180

E-mail: iza@iza.org

\begin{abstract}
Any opinions expressed here are those of the author(s) and not those of the institute. Research disseminated by IZA may include views on policy, but the institute itself takes no institutional policy positions.

The Institute for the Study of Labor (IZA) in Bonn is a local and virtual international research center and a place of communication between science, politics and business. IZA is an independent nonprofit company supported by Deutsche Post World Net. The center is associated with the University of Bonn and offers a stimulating research environment through its research networks, research support, and visitors and doctoral programs. IZA engages in (i) original and internationally competitive research in all fields of labor economics, (ii) development of policy concepts, and (iii) dissemination of research results and concepts to the interested public.
\end{abstract}

IZA Discussion Papers often represent preliminary work and are circulated to encourage discussion. Citation of such a paper should account for its provisional character. A revised version may be available directly from the author. 


\section{ABSTRACT \\ Minimum Wages, Minimum Labour Costs and the Tax Treatment of Low-Wage Employment ${ }^{*}$}

International comparisons of minimum-wage levels have largely focused on the gross value of minimum wages, ignoring the effects of taxation on both labour costs and the net income of employees. This paper presents estimates of the tax burdens facing minimum-wage workers. These are used as a basis for cross-country comparisons of the net earnings of these workers as well as the cost of employing them. In addition, results show the evolution of net incomes and labour costs during the 2000-2005 period and the relative importance of minimum-wage adjustments and tax reforms in driving these changes. Statutory minimum wages are in place in 21 OECD countries, ranging between USD 0.7 and USD 10 per hour. In a number of countries, minimum-wage levels have gone up in real terms in recent years. Given considerable tax burdens even at the lowest wage levels, tax policy measures can have a sizable impact on the net earnings available to low-wage workers. Social contributions and payroll taxes add, on average, around $18 \%$ to the cost of employing minimum-wage workers. The international variation of minimum labour costs in dollar terms is enormous, with hourly costs in the highest-cost country (the Netherlands) exceeding those at the bottom (Mexico) by a factor of 12 . Differences are also large when compared across countries that are closer geographically or whose economies are more integrated. Despite reductions in non-wage labour costs in several countries, there has been no convergence of minimum labour costs in recent years. This paper is the working paper version of a chapter to appear in the 2007 edition of Taxing Wages, an annual OECD publication. The Taxing Wages chapter will include results for 2006.

JEL Classification: J2, J3, H2, H3

Keywords: minimum wage, labour cost, taxation, OECD

Corresponding author:

Herwig Immervoll

OECD

Directorate for Employment, Labour and Social Affairs

Social Policy Division

2 , rue André-Pascal

75775 Paris Cedex 16

France

Email: herwig.immervoll@oecd.org

\footnotetext{
* The opinions expressed and arguments employed in this paper are the responsibility of the author and do not necessarily reflect those of the OECD.
} 
TABLE OF CONTENTS

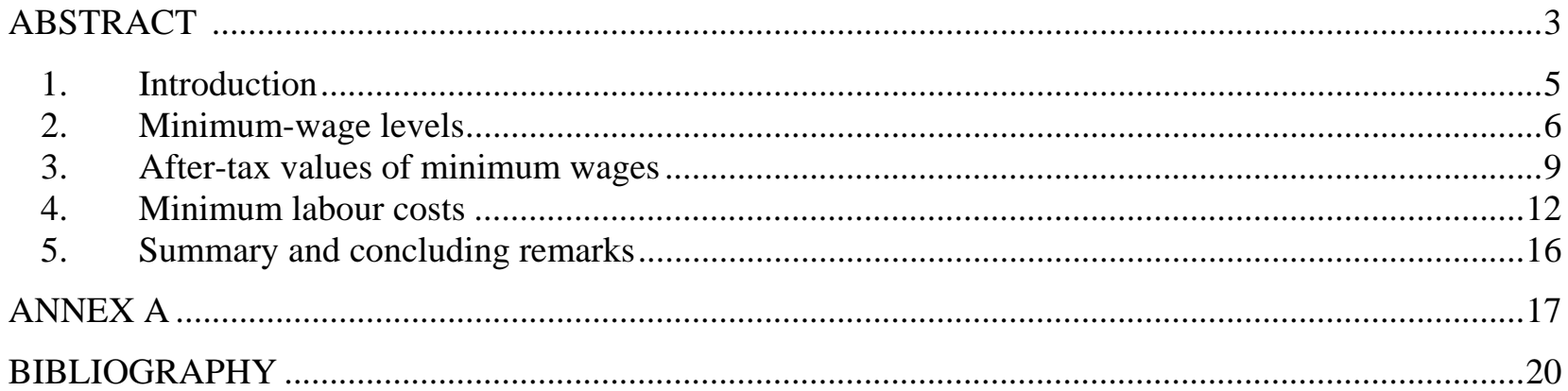

\section{Boxes}

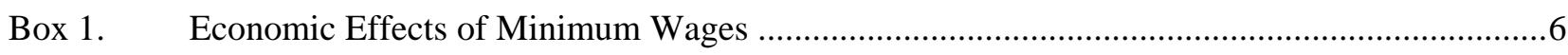

Tables

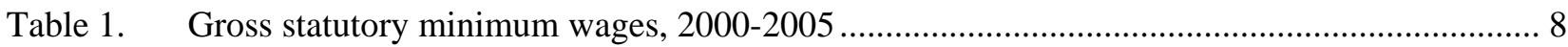

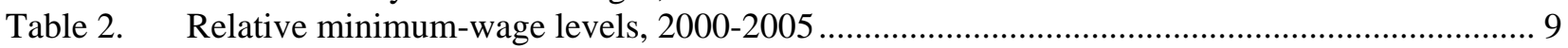

Table 3. Average tax rates for full-time workers at different wage levels .......................................... 10

Table 4. Payroll taxes and employer contributions for full-time workers at different wage levels........ 15

Table A1. Minimum wage levels used in the calculations .................................................................. 17

Table A2. Average wage levels used in the calculations..................................................................... 18

Table A3. Method used to calculate average earnings ......................................................................... 19

Figures

Figure 1. After-tax value of hourly minimum wage for a full-time worker .......................................... 11

Figure 2. Minimum labour cost for full-time minimum-wage workers ................................................ 14 


\section{Introduction}

4. Binding wage floors can have a significant impact on the wage distribution and the costs faced by employers. International comparisons of minimum-wage levels have largely focused on the gross value of minimum wages, ignoring the effects of taxation on both labour costs and the net income of employees. This paper presents estimates of the tax burdens facing minimum-wage workers. These are used as a basis for cross-country comparisons of the net earnings of these workers as well as the cost of employing them. In addition, results show the evolution of net incomes and labour costs during the past five years and the relative importance of minimum-wage adjustments and tax reforms in driving these changes.

5. Information on the cost of employing minimum-wage workers is useful for comparing the potential effect of statutory minima on firms' hiring decisions. Despite intensive research, there exists, in fact, little agreement, either in theory or in the empirical literature, about the net employment effects of minimum wages (see Box 1). There is a broad consensus, however, that employment is likely to be reduced if minimum wages are set "too high". Excessively high wage floors act as employment barriers for low-productivity workers in particular, with young people being a group of particular concern.

6. With binding wage floors in place, taxes paid by the employer cannot be passed on to minimumwage workers by lowering their pay (employers may nevertheless be able to shift taxes paid for minimumwage workers to higher-paid workers by lowering their wages). To the extent that minimum wages cause labour costs and worker productivity to become misaligned, they will then result in lower employment for the groups concerned. To alleviate the costs of employing low-productivity workers, a number of countries have therefore implemented measures to restrain non-wage labour costs specifically for workers whose wages are at or close to the legal minimum. To understand whether the cost of employing low-wage labour has in fact gone down after these policies were implemented, it is necessary to analyse employer contributions and payroll taxes in conjunction with trends of minimum-wage levels.

7. Similarly, policies to "make work pay" have targeted low-wage workers with the aim of increasing their take-home pay. In addition to the redistributive properties of such measures, spending tax revenue on improving the work incentives of low-wage workers can be attractive from an efficiency point of view as their labour supply is known to be particularly elastic (Immervoll et al., 2007). In a number of countries, "make work pay" policies have taken the form of tax reliefs or so-called "in work" benefits. But governments also seek to increase the returns to work more directly by adjusting wage floors. Different types of policy interventions may be employed simultaneously. For instance with minimum wages in place, it is more difficult for employers to "pocket" tax concessions aimed at improving employees' takehome pay and employment incentives. Again, given such complementarities and different strategies across countries, it is desirable to analyse relevant tax policy measures together with trends in minimum wages.

8. Section 2 provides an overview of minimum wages across countries using a range of different measures. Section 3 briefly describes the OECD's Taxing Wages models and uses them to calculate tax burdens and net incomes of minimum-wage earners. Section 4 then examines the cost of employing minimum-wage workers. All sections present results for 2000 and 2005. Observed trends are discussed in terms of the relative contributions of tax reforms and changes in minimum wages. 


\section{Box 1. Economic Effects of Minimum Wages}

With unchanged out-of-work benefits, higher wages improve incentives to take up employment and may increase employment in labour market segments where performance is inhibited by weak labour supply. And in a general equilibrium framework, additional wage income tends to increase consumption, notably among low-income households, which may have some positive effect on aggregate demand and, thus, employment.

But at the firm level, the imposition of a binding minimum wage increases labour costs leading to lower demand in a competitive labour market where firms can hire all the workers they need at a given wage. If this assumption is dropped, however, and replaced with one of an imperfect labour market where firms have to pay higher wages to recruit more workers, then it is possible that the minimum wage could actually increase employment - as well as output (Card and Krueger, 1995; Dolado et al., 1996; but already noted by Stigler, 1946). When set above a certain level (the workers' marginal product - which of course varies between employers and types of job), minimum wages will, however, reduce employers' demand for labour in this setting as well.

Empirical studies looking at the employment effects of altering minimum wage levels report conflicting results (OECD, 1998, chapter 2; OECD, 2006, chapter 3). In part, this is because they focus on different country settings, regions or labour market segments. But disagreement exists also between studies where these are similar. In a comprehensive survey of the "new minimum wage" literature, Neumark and Wascher (2006) conclude that the existing range of elasticities of employment with respect to changes in the minimum wage is very wide, that the majority of studies point towards disemployment effects, especially among the low-skilled population, and that there is comparatively little evidence of positive employment effects.

While employment effects have been the focus of minimum-wage related research, distributional concerns are commonly the primary rationale for introducing wage floors. The optimal level of any binding wage floor then depends on the relative weights attached to distributional and efficiency concerns. Of course, changes in the minimum wage do not reach the poorest segments of the population, i.e., households where no-one has a job. Yet, improving the incomes of low-wage workers may be a policy objective in itself and properly-set minimum wages can complement other policies in achieving it. In other words, although employment effects are a crucial influence on distributional outcomes as well, it is possible that, when set against other distortive redistributive measures, an optimal policy mix includes minimum wages even if they reduce employment among certain groups.

\section{Minimum-wage levels}

9. It is important to note that wage floors can exist even in the absence of statutory minimum wages. First, out-of-work benefits can act as a reservation wage with firms unable to find workers willing to accept wages below applicable benefit rates. Second, collectively-bargained minimum wages exist in some of the nine OECD countries who do not operate statutory minima. However, while the proportions of employees covered by such agreements can be large (for instance in Austria, Germany and Nordic countries), negotiated minimum wages tend to vary markedly between economic sectors, regions or depending on employer characteristics (for instance, more than 140 different collective agreements currently exist in Finland). For these reasons, negotiated wage floors are not considered in this chapter unless they are quasi-statutory. ${ }^{1}$ Information on unemployment and other out-of-work benefit levels can be found in the OECD series Benefits and Wages (OECD, 2004; 2007).

10. Statutory or quasi-statutory minimum wages are in place in 21 OECD countries. Data from the OECD minimum wage database, shown in Table 1, indicate that the variation across countries is very substantial, with 2005 levels ranging between about USD 1 and USD 10 per hour for adult workers.

1. While not directly set by law, decisions by judicial bodies or agreements between social partners can result in wage floors that are legally binding or equivalent in terms of coverage and universality to statutory minima. Examples are Australia, Belgium and Greece. 
11. While comparing absolute wage levels in a common currency can be informative, international comparisons frequently express minimum wages relative to the earnings distribution in each country.

12. The relative position of minimum-wage workers is of interest both as a feature of the income distribution and because it is indicative of the economic significance of wage floors for the labour market. While, arithmetically, the most obvious effect of introducing or raising minimum wages is to change the earnings of those below the new wage floor, there will generally be spill-over effects on the wages of those further up the earnings distribution. For instance, a recent study argues that the large minimum wage increase in Hungary in January 2001, which introduced a wage floor at around the $15^{\text {th }}$ earnings percentile, resulted in progressively smaller, but measurable, wage increases up until the $35^{\text {th }}$ percentile (Kertesi and Köllõ, 2003). ${ }^{2}$

13. Table 2 shows gross earnings of full-time minimum-wage workers as a percentage of average wages of full-time workers in industry sectors C-K (see annex Table A2). ${ }^{3,4}$ They range from roughly $25 \%$ in Korea and Mexico to around 50\% in Australia, France, Ireland, the Netherlands and New Zealand. On average across the 21 countries, minimum wages in 2005 amount to nearly $38 \%$ of AW.

14. Between 2000 and 2005, the simple (un-weighted) country average has increased slightly, indicating that minimum-wage workers have tended to participate equally in the wage gains or losses experienced by the working population at large. Some countries have, however, seen substantial changes over the past five years. The United States stands out as the only country where minimum-wage workers have seen their real earnings decline markedly and persistently (see Table 1, which shows that Belgian and Canadian real minimum wages have declined as well but only marginally so). As the nominal value of the Federal minimum wage has not been increased since 1998, inflation has eroded its real value. Gross earnings of minimum-wage earners have fallen behind those of the average US employee by five percentage points over the period. Minimum wages have also lagged behind average wage growth in Australia, Belgium, Greece, Mexico, the Netherlands and Portugal.

2. Recent experimental evidence also suggests that employees adjust their wage expectations following changes in the minimum wage and that this affects the labour supply schedule prompting employers to consider paying wages above the legal minimum (Falk et al., forthcoming).

3. It would arguably be more informative to construct a relative measure in relation to median wages, which are, however, currently not available on a consistent basis across countries.

4. All results shown in this chapter relate to full-time workers. It should be noted that part-time work is common among low-wage employees. As a result of progressive tax systems, tax burdens (and possibly labour costs) of part-time minimum-wage workers will tend to be lower than indicated by the tax burden measures shown here. 
Table 1. Gross statutory minimum wages, 2000-2005

Per hour, USD at 2005 market exchange rates and constant prices

\begin{tabular}{|c|c|c|c|c|c|c|}
\hline & 2000 & 2001 & 2002 & 2003 & 2004 & 2005 \\
\hline Australia & 8.57 & 8.52 & 8.56 & 8.69 & 8.83 & 8.93 \\
\hline Belgium & 9.24 & 9.25 & 9.35 & 9.32 & 9.25 & 9.21 \\
\hline Canada & 6.17 & 6.11 & 6.04 & 5.96 & 5.97 & 6.02 \\
\hline Czech Republic & 1.09 & 1.34 & 1.50 & 1.63 & 1.71 & 1.80 \\
\hline France & 8.62 & 8.79 & 8.90 & 9.05 & 9.36 & 9.72 \\
\hline Greece & 4.67 & 4.67 & 4.75 & 4.82 & 4.93 & 5.03 \\
\hline Hungary & 0.98 & 1.41 & 1.67 & 1.60 & 1.59 & 1.65 \\
\hline Ireland & 8.26 & 8.14 & 8.16 & 8.26 & 8.85 & 9.24 \\
\hline Japan & 5.81 & 5.90 & 5.99 & 6.00 & 6.01 & 6.04 \\
\hline Korea & 2.02 & 2.12 & 2.37 & 2.54 & 2.68 & 2.90 \\
\hline Luxembourg & 9.69 & 10.03 & 10.01 & 10.39 & 10.31 & 10.58 \\
\hline Mexico & 0.72 & 0.72 & 0.73 & 0.73 & 0.73 & 0.73 \\
\hline Netherlands & 10.43 & 10.61 & 10.73 & 10.84 & 10.78 & 10.60 \\
\hline New Zealand & 6.00 & 5.97 & 6.04 & 6.31 & 6.52 & 6.69 \\
\hline Poland & 1.31 & 1.45 & 1.44 & 1.51 & 1.50 & 1.51 \\
\hline Portugal & 3.11 & 3.13 & 3.15 & 3.13 & 3.13 & 3.13 \\
\hline Slovak Republic & 0.95 & 0.98 & 1.08 & 1.17 & 1.18 & 1.22 \\
\hline Spain & 4.12 & 4.07 & 4.04 & 4.01 & 4.15 & 4.27 \\
\hline Turkey & 1.22 & 0.99 & 1.12 & 1.16 & 1.49 & 1.52 \\
\hline United Kingdom & 7.88 & 8.27 & 8.66 & 8.82 & 9.20 & 9.47 \\
\hline United States & 5.84 & 5.68 & 5.59 & 5.47 & 5.32 & 5.15 \\
\hline$O E C D-21$ & 5.08 & 5.15 & 5.23 & 5.30 & 5.40 & 5.50 \\
\hline
\end{tabular}

Source: Calculations based on the OECD Minimum Wage Database. See Annex Table A1 for details.

15. In a number of other countries, the gap between minimum and average wages has narrowed. Relative minimum-wage levels have increased from very low initial levels in Turkey and from moderate levels in the United Kingdom and most Eastern European countries. Minimum-wage workers in France and New Zealand have benefited from further increases of relative wage floors that were already among the highest in the OECD.

16. Despite a number of minimum-wage increases, relative wage floors in Ireland have remained largely unchanged over the 2000-2005 period as a result of equally large wage increases in other parts of the earnings distribution. 
Table 2. Relative minimum-wage levels, 2000-2005

Gross earnings of full-time minimum-wage workers as \% of gross average wages

\begin{tabular}{lrrrrrr} 
& 2000 & 2001 & 2002 & 2003 & 2004 & 2005 \\
\cline { 2 - 7 } Australia & $50 \%$ & $51 \%$ & $50 \%$ & $49 \%$ & $48 \%$ & $48 \%$ \\
Belgium & $42 \%$ & $41 \%$ & $41 \%$ & $41 \%$ & $40 \%$ & $40 \%$ \\
Canada & $38 \%$ & $38 \%$ & $38 \%$ & $38 \%$ & $38 \%$ & $38 \%$ \\
Czech Republic & $30 \%$ & $36 \%$ & $38 \%$ & $40 \%$ & $40 \%$ & $41 \%$ \\
France & $43 \%$ & $43 \%$ & $44 \%$ & $44 \%$ & $45 \%$ & $47 \%$ \\
Greece & $43 \%$ & $43 \%$ & $43 \%$ & $43 \%$ & $41 \%$ & $39 \%$ \\
Hungary & $28 \%$ & $38 \%$ & $42 \%$ & $39 \%$ & $37 \%$ & $38 \%$ \\
Ireland & $53 \%$ & $51 \%$ & $49 \%$ & $51 \%$ & $50 \%$ & $53 \%$ \\
Japan & $27 \%$ & $27 \%$ & $28 \%$ & $28 \%$ & $28 \%$ & $28 \%$ \\
Korea & $22 \%$ & $22 \%$ & $23 \%$ & $24 \%$ & $23 \%$ & $25 \%$ \\
Luxembourg & $40 \%$ & $41 \%$ & $41 \%$ & $42 \%$ & $41 \%$ & $42 \%$ \\
Mexico & $27 \%$ & $25 \%$ & $25 \%$ & $24 \%$ & $24 \%$ & $24 \%$ \\
Netherlands & $49 \%$ & $49 \%$ & $49 \%$ & $48 \%$ & $47 \%$ & $46 \%$ \\
New Zealand & $45 \%$ & $44 \%$ & $45 \%$ & $46 \%$ & $47 \%$ & $48 \%$ \\
Poland & $33 \%$ & $34 \%$ & $33 \%$ & $34 \%$ & $34 \%$ & $36 \%$ \\
Portugal & $41 \%$ & $41 \%$ & $40 \%$ & $40 \%$ & $39 \%$ & $39 \%$ \\
Slovak Republic & $31 \%$ & $32 \%$ & $34 \%$ & $38 \%$ & $37 \%$ & $37 \%$ \\
Spain & $34 \%$ & $34 \%$ & $33 \%$ & $33 \%$ & $34 \%$ & $35 \%$ \\
\hline Turkey & $18 \%$ & $16 \%$ & $19 \%$ & $21 \%$ & $27 \%$ & $27 \%$ \\
United Kingdom & $32 \%$ & $33 \%$ & $33 \%$ & $34 \%$ & $35 \%$ & $35 \%$ \\
United States & $39 \%$ & $38 \%$ & $37 \%$ & $36 \%$ & $35 \%$ & $34 \%$ \\
\hline OECD-21 & $36 \%$ & $37 \%$ & $37 \%$ & $38 \%$ & $38 \%$ & $38 \%$
\end{tabular}

Note: The available average wage figure for the US currently excludes supervisory and managerial workers. The ratios shown for the US would therefore be considerably lower if US average wages were available on the same basis as in other countries. Average wages for Ireland, Korea and Turkey refer to the Average Production Worker (manual workers in the manufacturing industry).

Source: Calculations based on the OECD Minimum Wage Database. See Annex Tables A2 and A3 for details on the average wage measures used.

\section{After-tax values of minimum wages}

17. One policy objective of introducing or increasing minimum wages is to improve the incomes of low-skilled workers. The tax treatment of low wages plays an important role in determining the extent to which higher minimum wages do in fact translate into net income gains.

18. The OECD series Taxing Wages provides some insight into the tax treatment of low-wage workers. Using tax calculation models constructed and maintained jointly with tax administrations in each OECD country, Taxing Wages provides an annual analysis of tax burdens faced by employees and their employers at different earnings levels, down to two thirds (67\%) of the average wage (see OECD, 2007b for further details).

19. It is clear from Table 2, however, that minimum-wage levels are substantially below this lowwage cut-off. It is therefore possible that relevant aspects of tax policy measures directed at the very bottom of the wage distribution may not in fact be picked up by the standard measures considered in Taxing Wages. 
20. Table 3 shows results from the OECD tax calculation models and indicates that tax burdens can indeed differ significantly between "low" (67\% of AW) and "lowest" (minimum wage) earnings levels. Results are shown for single individuals only. ${ }^{5}$

\section{Table 3. Average tax rates for full-time workers at different wage levels}

Personal income tax plus employee social security contributions

\begin{tabular}{|c|c|c|c|c|c|c|}
\hline & \multicolumn{3}{|c|}{2000} & \multicolumn{3}{|c|}{2005} \\
\hline & MW & $67 \%$ AW & AW & MW & $67 \%$ AW & AW \\
\hline Australia & $15.4 \%$ & $20.7 \%$ & $26.1 \%$ & $15.3 \%$ & $20.3 \%$ & $24.0 \%$ \\
\hline Austria & & $25.6 \%$ & $31.0 \%$ & & $26.6 \%$ & $32.7 \%$ \\
\hline Belgium & $23.5 \%$ & $35.8 \%$ & $43.0 \%$ & $18.8 \%$ & $34.8 \%$ & $41.9 \%$ \\
\hline Canada & $15.3 \%$ & $19.6 \%$ & $25.4 \%$ & $13.7 \%$ & $19.0 \%$ & $23.9 \%$ \\
\hline Czech Republic & $14.9 \%$ & $20.8 \%$ & $22.6 \%$ & $19.3 \%$ & $21.7 \%$ & $24.1 \%$ \\
\hline Denmark & & $40.8 \%$ & $44.1 \%$ & & $38.7 \%$ & $40.8 \%$ \\
\hline Finland & & $28.1 \%$ & $34.2 \%$ & & $25.0 \%$ & $31.3 \%$ \\
\hline France & $21.0 \%$ & $25.7 \%$ & $28.8 \%$ & $17.6 \%$ & $26.0 \%$ & $29.0 \%$ \\
\hline Germany & & $38.1 \%$ & $44.5 \%$ & & $36.4 \%$ & $42.5 \%$ \\
\hline Greece & $15.9 \%$ & $17.4 \%$ & $21.1 \%$ & $16.0 \%$ & $16.5 \%$ & $23.7 \%$ \\
\hline Hungary & $20.5 \%$ & $30.0 \%$ & $35.7 \%$ & $13.5 \%$ & $22.2 \%$ & $33.7 \%$ \\
\hline Iceland & & $15.9 \%$ & $22.6 \%$ & & $19.3 \%$ & $24.9 \%$ \\
\hline Ireland & $8.3 \%$ & $11.1 \%$ & $20.3 \%$ & $3.8 \%$ & $7.9 \%$ & $15.3 \%$ \\
\hline Italy & & $23.7 \%$ & $28.2 \%$ & & $22.4 \%$ & $27.3 \%$ \\
\hline Japan & $12.2 \%$ & $15.5 \%$ & $17.0 \%$ & $14.0 \%$ & $17.1 \%$ & $18.5 \%$ \\
\hline Korea & $6.7 \%$ & $7.4 \%$ & $9.0 \%$ & $7.1 \%$ & $8.1 \%$ & $9.9 \%$ \\
\hline Luxembourg & $17.0 \%$ & $23.5 \%$ & $30.1 \%$ & $15.7 \%$ & $20.7 \%$ & $27.3 \%$ \\
\hline Mexico & $-24.5 \%$ & $-4.6 \%$ & $2.4 \%$ & $-23.0 \%$ & $-2.1 \%$ & $4.6 \%$ \\
\hline Netherlands & $28.0 \%$ & $32.6 \%$ & $33.2 \%$ & $23.8 \%$ & $31.9 \%$ & $32.5 \%$ \\
\hline New Zealand & $17.4 \%$ & $18.6 \%$ & $19.4 \%$ & $18.1 \%$ & $18.9 \%$ & $20.4 \%$ \\
\hline Norway & & $26.7 \%$ & $30.7 \%$ & & $25.6 \%$ & $29.0 \%$ \\
\hline Poland & $26.5 \%$ & $30.4 \%$ & $31.6 \%$ & $26.7 \%$ & $30.5 \%$ & $31.9 \%$ \\
\hline Portugal & $12.2 \%$ & $17.3 \%$ & $22.4 \%$ & $11.0 \%$ & $15.6 \%$ & $21.2 \%$ \\
\hline Slovak Republic & $12.5 \%$ & $17.9 \%$ & $19.5 \%$ & $13.4 \%$ & $18.3 \%$ & $22.1 \%$ \\
\hline Spain & $6.4 \%$ & $14.7 \%$ & $19.8 \%$ & $6.4 \%$ & $15.8 \%$ & $20.2 \%$ \\
\hline Sweden & & $31.7 \%$ & $33.7 \%$ & & $29.2 \%$ & $31.3 \%$ \\
\hline Switzerland & & $18.9 \%$ & $22.0 \%$ & & $18.6 \%$ & $21.8 \%$ \\
\hline Turkey & $24.1 \%$ & $27.2 \%$ & $28.7 \%$ & $28.4 \%$ & $29.5 \%$ & $30.5 \%$ \\
\hline United Kingdom & $11.7 \%$ & $22.2 \%$ & $25.5 \%$ & $11.0 \%$ & $23.5 \%$ & $26.6 \%$ \\
\hline United States & $16.3 \%$ & $21.1 \%$ & $23.9 \%$ & $14.8 \%$ & $20.5 \%$ & $23.3 \%$ \\
\hline Average & $14.3 \%$ & $22.5 \%$ & $26.6 \%$ & $13.6 \%$ & $21.9 \%$ & $26.2 \%$ \\
\hline
\end{tabular}

Notes: AW: average wage, MW: statutory minimum wage. The average wage for the US currently excludes supervisory and managerial workers. Average wages for Ireland, Korea and Turkey refer to the Average Production Worker (manual workers in the manufacturing industry).

Source: OECD Taxing Wages calculation files (OECD, 2007b). See Annex Tables A2 and A3 for details on the average wage measures used.

5. Countries also operate a number of tax and benefit provisions affecting low-wage earners in other family situations - particularly where children are present (OECD, 2004). Because such provisions also reflect family-related tax policy objectives, they are not considered here although they can of course be relevant for minimum-wage earners. 
21. In 2005, average tax rates of minimum-wage earners in the Netherlands, Poland and Turkey have exceeded 20\%. Yet, 11 countries have eased tax burdens in recent years. Over the 2000-2005 period, tax reductions for minimum-wage workers have been most prominent in Belgium, France, Ireland, and the Netherlands and, in spite of a large increase in minimum wage levels, in Hungary. In these countries, tax burdens of average workers have fallen less strongly during this period. As a result, tax systems in these countries have tended to become more progressive in the lower half of the earnings distribution.

22. The resulting minimum wages net of income taxes and employee social security contributions are displayed in Figure 1a. With progressive tax systems, minimum wages expressed as a percentage of the average wage are larger in net terms than they are on a gross basis. In a number of countries, this progressivity provides a sizable boost to the incomes of minimum-wage earners relative to those of average earners. While the largest equalising effect is found for the country with the highest labour tax burdens for average wage earners (Belgium), the difference between the tax rates faced by average and minimum-wage earners is also substantial in Hungary (19 percentage points) and the United Kingdom (16 percentage points). In Mexico, a generous non-wastable tax credit available to low-wage earners produces a negative tax burden for full-time minimum-wage workers.

23. After adjusting for differences in prices an exchange rates across countries using purchasing power parities (PPPs) for 2005, one hour of work in a full-time minimum-wage job is shown to pay most in Western European countries and in Australia, at a PPP equivalent of around USD 7.00 (Figure 1b). At about USD 4.40, the spending power of US and Japanese minimum-wage workers is significantly lower. As might be expected, the purchasing power of minimum-wage earners is lowest in the lower-income OECD countries. Since 2000, the net value of minimum-wage work has, however, gone up very significantly in the Czech Republic and has almost doubled in Hungary (relative to net average wages, the net earnings of full-time minimum wage workers in these latter two countries are now at or above the OECD-21 average of 43\%).

Figure 1. After-tax value of hourly minimum wage for a full-time worker

(a) as $\%$ of the net average wage

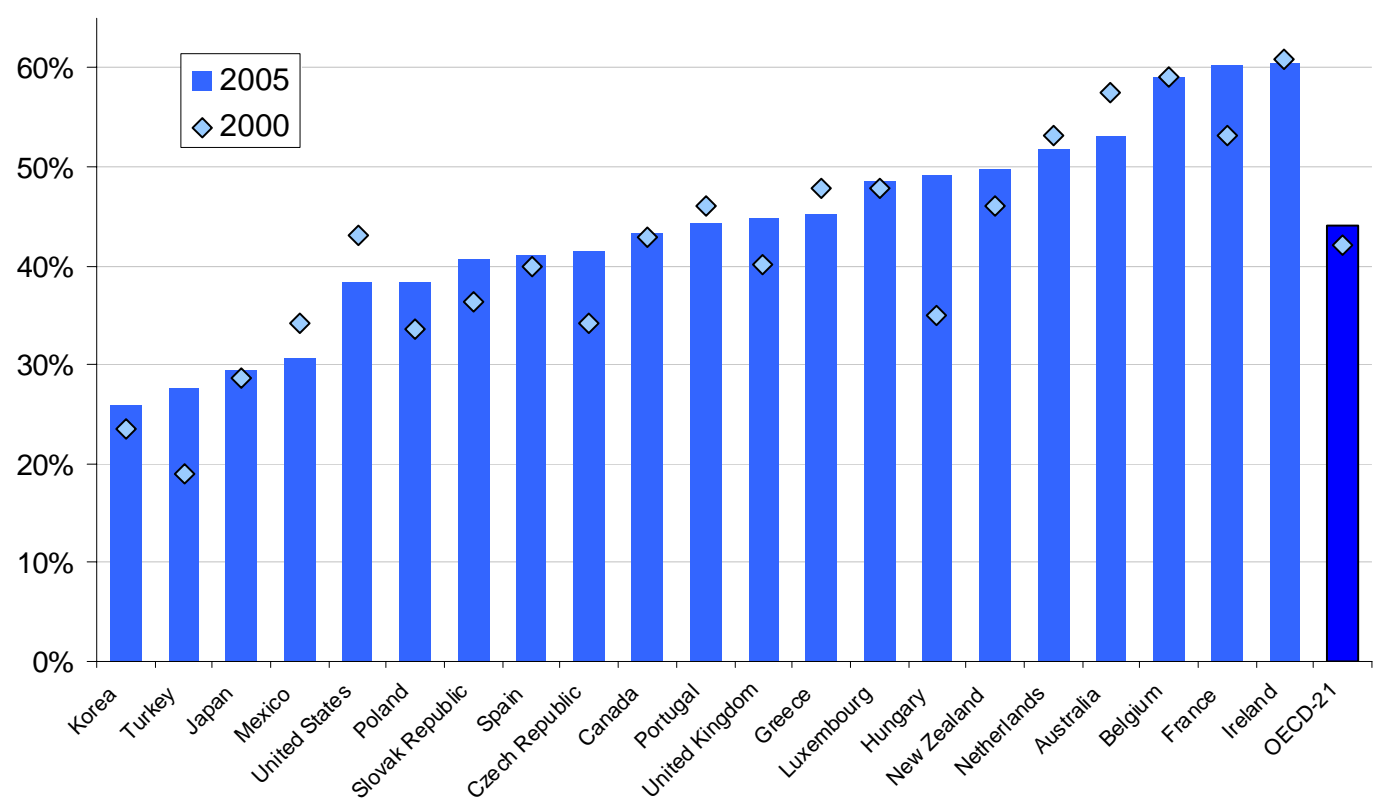


(b) in USD at 2005 purchasing power parities

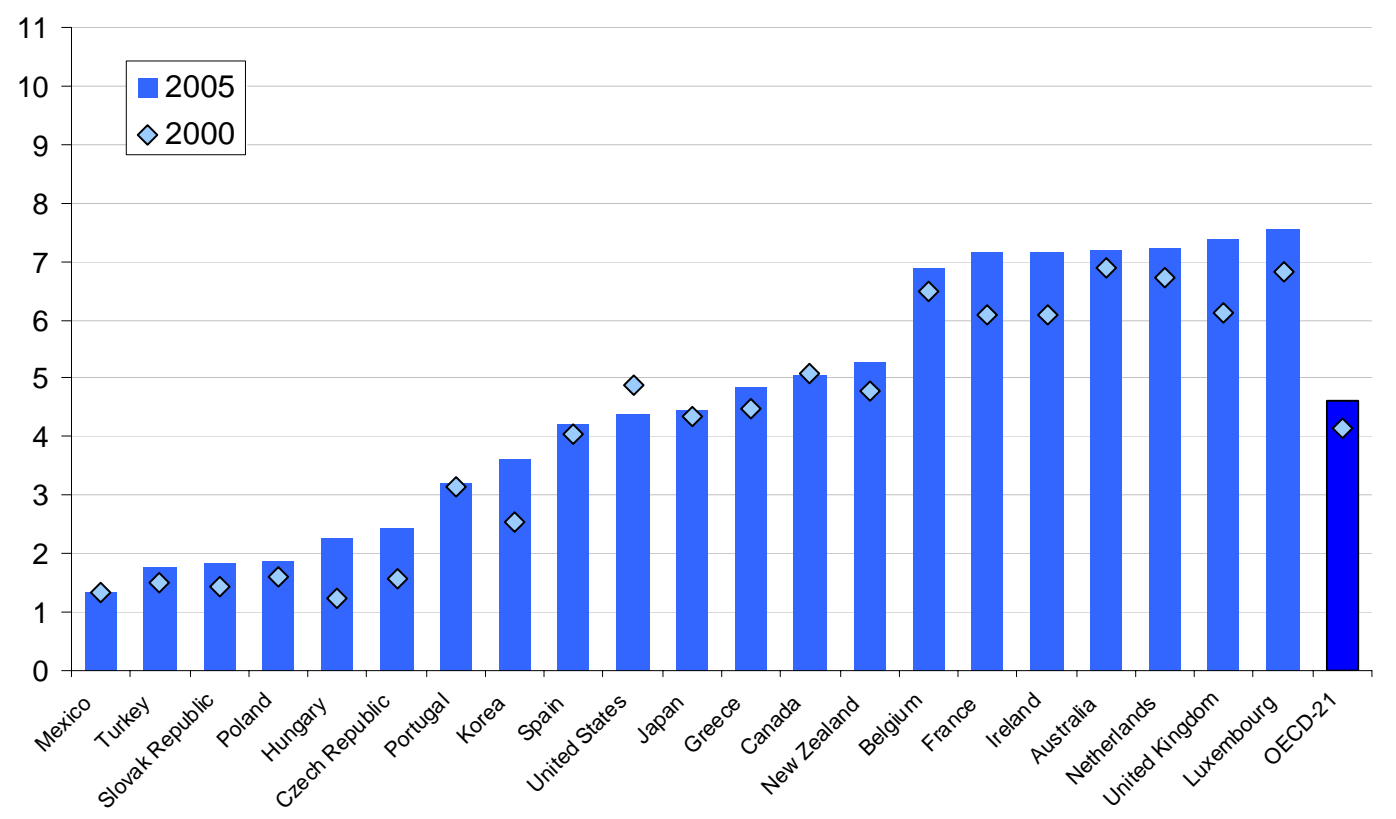

Note: The average wage for the US currently excludes supervisory and managerial workers. Average wages for Ireland, Korea and Turkey refer to the Average Production Worker (manual workers in the manufacturing industry).

Source: OECD Taxing Wages calculation files (OECD, 2007b). See Annex Tables A2 and A3 for details on the average wage measures used.

\section{Minimum labour costs}

24. While increased net wages can ease barriers on the supply-side of the labour market, high minimum wages can "price" low-productivity workers out of the labour market, giving rise to concerns that minimum wages may result in adverse employment effects. Whether these concerns are justified depends on the structure of the labour market, worker productivity, and the cost of employing minimumwage labour.

25. A number of different perspectives are possible when assessing this cost. Similar to the analysis of net minimum wages, minimum labour costs can be expressed relative to the cost of employing workers at an average wage level. Other things equal, a small difference between minimum and average labour costs makes it more likely that wage floors are binding in the sense that they increase employer costs. While there is no agreement on the overall employment effect of minimum-wage increases, a more binding wage floor increases the likelihood that at least some low-productivity workers would face difficulties finding a job. Similarly, the cost difference between lower and higher-skilled workers can be expected to have some influence on the sectoral composition of economic activity within a country.

26. In addition, it is useful to evaluate the absolute cost advantage or disadvantage of minimum wage workers between countries. On one hand, and along with other factors, cost disparities between countries can shape the incentives for employers to re-locate or out-source labour-intensive and "low-value added" activities. On the other hand, absolute differences in minimum labour costs can indicate by how much the productivity of minimum-wage workers in "high-cost" countries would have to exceed that of "low-cost" countries in order to neutralise this potential cost advantage. 
27. On average across 21 OECD countries, employers pay slightly more than USD 6.00 for one hour of minimum-wage labour. This is shown in Figure 2a, which accounts for both payroll taxes and mandatory social contributions payable by the employer. Compared to the year 2000, this represents an increase of about $8 \%$ in real terms. As gross minimum wages have grown at approximately the same rate, this indicates that payroll taxes and employer contributions have, on average, tended to remain largely unchanged over that period.

28. The international variation of minimum labour costs in dollar terms is enormous, however, with hourly costs in the highest-cost country (the Netherlands) exceeding those at the bottom (Mexico) by a factor of $12 .{ }^{6}$ Differences are also large when compared across countries that are closer geographically or whose economies are more integrated. For instance, the minimum labour cost in the United States is roughly six times as high as in Mexico but $20 \%$ lower than in Canada. Australian minimum labour costs exceed those in New Zealand by 43\%. In Europe, the cost of employing French minimum-wage workers is three times as high as in Portugal, despite recent reductions of French social charges for low-wage workers. Finally, minimum labour costs in the Slovak Republic are more than 30\% lower than in neighbouring Hungary and the Czech Republic.

29. The variation across countries is still substantial when accounting for differences in average wage levels. This is shown in Figure 2b, which compares the cost of employing minimum-wage workers with the cost of average-wage workers. Minimum wage costs range from less than $30 \%$ of the cost of an average worker in Japan, Korea, Mexico, Spain and Turkey to almost 50\% in Australia, Ireland, the Netherlands and New Zealand.

30. In most countries, the cost of employing minimum-wage workers has gone up in recent years, both in real terms and relative to the labour cost for workers earning average wages. The trends are, in fact largely similar to those observed for net minimum wages. One exception to this pattern is Belgium, where a combination of lower tax burdens and minimum-wage increases below inflation have enhanced net incomes of minimum-wage workers while keeping labour costs unchanged.

6. It should be noted, however, that most of the "high minimum labour cost" countries employ differentiated minimum-wage schedules that employ lower minima for younger workers (see annex Table A1). 
Figure 2. Minimum labour cost for full-time minimum-wage workers

(a) per hour, USD at 2005 market exchange rates and constant prices

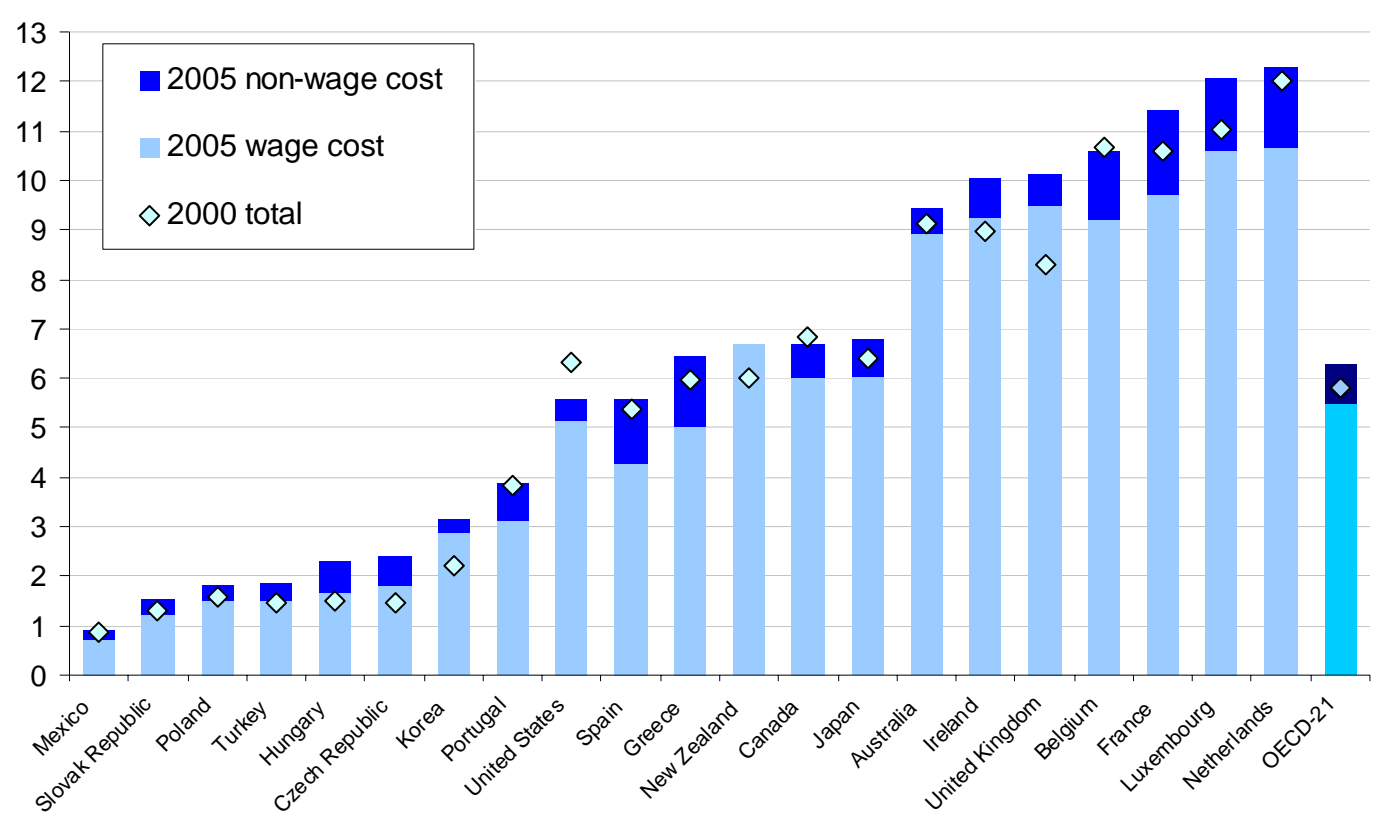

(b) as \% of labour cost for an average earner

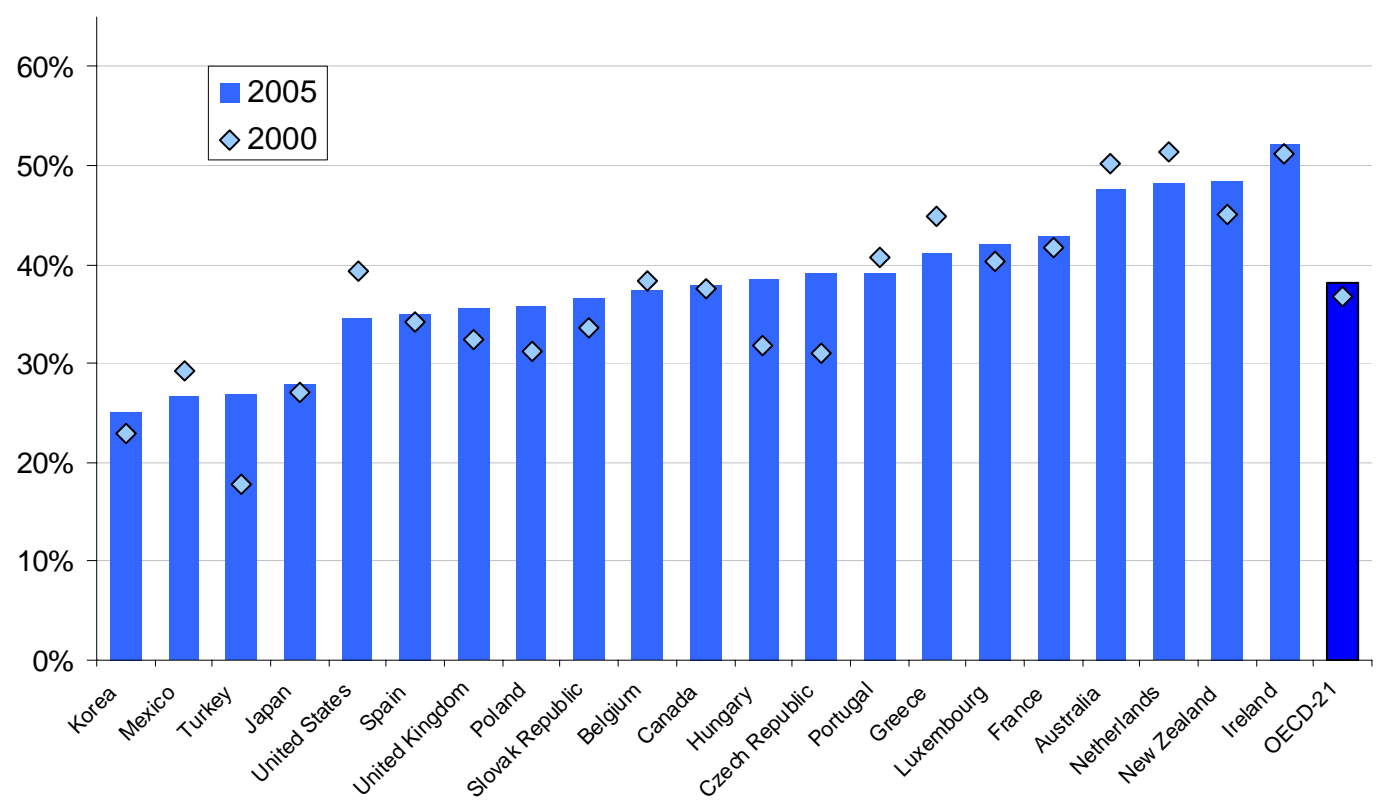

Note: Including payroll taxes and mandatory social contributions. The average wage for the US currently excludes supervisory and managerial workers. Average wages for Ireland, Korea and Turkey refer to the Average Production Worker (manual workers in the manufacturing industry).

Source: OECD Taxing Wages calculation files (OECD, 2007b). See Annex Tables A2 and A3 for details on the average wage measures used. 


\section{Non-wage labour costs}

31. Figure 2a also shows that non-wage labour costs can represent a substantial part of the total cost to employers. For full-time minimum-wage workers, payroll taxes and mandatory social contributions are found to increase employment costs by more than 30\% in the Czech Republic, Hungary and Spain but by less than $10 \%$ in Korea and most English-speaking countries (see also Table 4). Non-wage labour costs are also substantial in some of the countries without statutory minimum wages (Austria, Finland, Germany, Italy and Sweden). Most countries charge similar rates of payroll taxes and employer social contributions for minimum-wage labour as for higher-earning employees. Preferential rates for minimum-wage workers are found in only four countries (Belgium, France, Ireland and the UK).

Table 4. Payroll taxes and employer contributions for full-time workers at different wage levels

\begin{tabular}{|c|c|c|c|c|c|c|}
\hline & \multicolumn{3}{|c|}{$\begin{array}{l}\text { As } \% \text { of gross wages } \\
2000\end{array}$} & \multicolumn{3}{|c|}{2005} \\
\hline & MW & $67 \%$ AW & AW & MW & $67 \%$ AW & AW \\
\hline Australia & $6.4 \%$ & $6.4 \%$ & $6.4 \%$ & $6.0 \%$ & $6.0 \%$ & $6.0 \%$ \\
\hline Austria & & $31.0 \%$ & $31.0 \%$ & & $29.1 \%$ & $29.1 \%$ \\
\hline Belgium & $15.4 \%$ & $31.9 \%$ & $32.9 \%$ & $15.1 \%$ & $28.2 \%$ & $30.4 \%$ \\
\hline Canada & $11.0 \%$ & $11.4 \%$ & $11.6 \%$ & $11.1 \%$ & $11.6 \%$ & $11.7 \%$ \\
\hline Czech Republic & $35.0 \%$ & $35.0 \%$ & $35.0 \%$ & $35.0 \%$ & $35.0 \%$ & $35.0 \%$ \\
\hline Denmark & & $0.7 \%$ & $0.5 \%$ & & $0.8 \%$ & $0.6 \%$ \\
\hline Finland & & $26.0 \%$ & $26.0 \%$ & & $24.0 \%$ & $24.0 \%$ \\
\hline France & $23.0 \%$ & $41.2 \%$ & $41.2 \%$ & $17.6 \%$ & $27.2 \%$ & $42.3 \%$ \\
\hline Germany & & $20.5 \%$ & $20.5 \%$ & & $20.7 \%$ & $20.7 \%$ \\
\hline Greece & $28.0 \%$ & $28.0 \%$ & $28.0 \%$ & $28.1 \%$ & $28.1 \%$ & $28.1 \%$ \\
\hline Hungary & $52.8 \%$ & $44.0 \%$ & $41.8 \%$ & $39.1 \%$ & $36.7 \%$ & $35.6 \%$ \\
\hline Iceland & & $4.8 \%$ & $4.8 \%$ & & $5.7 \%$ & $5.7 \%$ \\
\hline Ireland & $8.5 \%$ & $8.5 \%$ & $12.0 \%$ & $8.5 \%$ & $10.8 \%$ & $10.8 \%$ \\
\hline Italy & & $34.1 \%$ & $34.1 \%$ & & $33.1 \%$ & $33.1 \%$ \\
\hline Japan & $10.3 \%$ & $10.3 \%$ & $10.3 \%$ & $12.8 \%$ & $12.8 \%$ & $12.8 \%$ \\
\hline Korea & $8.9 \%$ & $8.9 \%$ & $8.9 \%$ & $9.0 \%$ & $9.0 \%$ & $9.0 \%$ \\
\hline Luxembourg & $13.8 \%$ & $13.8 \%$ & $13.8 \%$ & $14.0 \%$ & $13.7 \%$ & $13.5 \%$ \\
\hline Mexico & $21.8 \%$ & $12.7 \%$ & $11.7 \%$ & $25.7 \%$ & $13.4 \%$ & $11.8 \%$ \\
\hline Netherlands & $15.3 \%$ & $16.1 \%$ & $10.7 \%$ & $16.1 \%$ & $16.8 \%$ & $10.5 \%$ \\
\hline New Zealand & $0.0 \%$ & $0.0 \%$ & $0.0 \%$ & $0.0 \%$ & $0.0 \%$ & $0.0 \%$ \\
\hline Norway & & $12.8 \%$ & $12.8 \%$ & & $13.1 \%$ & $13.1 \%$ \\
\hline Poland & $19 \%$ & $20.4 \%$ & $20.4 \%$ & $17.9 \%$ & $20.5 \%$ & $20.5 \%$ \\
\hline Portugal & $23.8 \%$ & $23.8 \%$ & $23.8 \%$ & $23.8 \%$ & $23.8 \%$ & $23.8 \%$ \\
\hline Slovak Republic & $38.2 \%$ & $38.2 \%$ & $38.2 \%$ & $26.2 \%$ & $26.2 \%$ & $26.2 \%$ \\
\hline Spain & $30.6 \%$ & $30.6 \%$ & $30.6 \%$ & $30.6 \%$ & $30.6 \%$ & $30.6 \%$ \\
\hline Sweden & & $32.9 \%$ & $32.9 \%$ & & $32.5 \%$ & $32.5 \%$ \\
\hline Switzerland & & $11.6 \%$ & $11.6 \%$ & & $11.1 \%$ & $11.1 \%$ \\
\hline Turkey & $19.5 \%$ & $19.5 \%$ & $19.5 \%$ & $21.5 \%$ & $21.5 \%$ & $21.5 \%$ \\
\hline United Kingdom & $5.2 \%$ & $8.8 \%$ & $9.9 \%$ & $6.7 \%$ & $9.6 \%$ & $10.7 \%$ \\
\hline United States & $8.2 \%$ & $8.0 \%$ & $7.9 \%$ & $8.2 \%$ & $7.9 \%$ & $7.8 \%$ \\
\hline Average & $18.8 \%$ & $19.7 \%$ & $19.6 \%$ & $17.8 \%$ & $18.6 \%$ & $18.9 \%$ \\
\hline
\end{tabular}

Notes: AW: average wage, MW: statutory minimum wage. The average wage for the US currently excludes supervisory and managerial workers. Average wages for Ireland, Korea and Turkey refer to the Average Production Worker (manual workers in the manufacturing industry).

Source: OECD Taxing Wages calculation files (OECD, 2007b). See Annex Tables A2 and A3 for details on the average wage measures used. 
32. In countries where the cost of employing unskilled or low-productivity workers is considered to be a barrier to employment, reducing social charges can be effective at reducing labour costs. Belgium and France, two countries with particularly high levels of non-wage labour costs, have implemented targeted reductions of employer contributions. In both countries, the relevant rates for a full-time minimum-wage worker are now less than half of those applicable to average earners. Yet, as a result of high minimumwage levels, the total cost of employing minimum-wage workers in these countries is still among the highest in the OECD.

33. Averaged across countries, reductions in payroll tax and contribution burdens on minimum-wage labour over the 2000-2005 period have been more modest. Rates have, in fact, gone up in Hungary, Japan, Turkey and the United Kingdom. Unlike in Belgium and France, where reductions of non-wage labour costs were targeted towards low-wage workers in particular, the Slovak Republic has implemented substantial across-the-board cuts and reduced non-wage labour costs at all earnings levels.

\section{Summary and concluding remarks}

34. Statutory minimum wages are in place in 21 OECD countries, ranging between USD 0.7 and USD 10 per hour. In a number of countries, minimum-wage levels have gone up in real terms in recent years. During the 2000-2005 period, the most substantial increases were observed in Czech Republic and Hungary (plus 65\%). In a slight majority of countries, minimum wages have also increased relative to average wage levels. The United States is the only country where real earnings of minimum-wage workers have dropped significantly during this period. In 2005, the full-time earnings of minimum-wage workers ranged from to less than 25\% of full-time average wages in Mexico to more than 50\% in Ireland.

35. While income tax systems are progressive and tax burdens correspondingly lower for minimumwage workers, the income taxes and social contributions they pay are considerable (between $15 \%$ and $28 \%$ in half of the countries). Social contributions paid by minimum-wage earners exceed income taxes in most countries and tend to be the main drivers of overall tax burdens.

36. Given considerable tax burdens even at the lowest wage levels, tax policy measures can have a sizable impact on the net earnings available to low-wage workers. Indeed, the comparison across countries shows that average tax rates for single minimum-wage earners have declined since 2000, and that a number of European countries have implemented tax reductions targeted at the lowest wage levels. Such targeted tax reductions improve the incomes of minimum-wage workers as employers cannot lower wages in response. Since low-skilled individuals tend to respond more readily to financial work incentives than those with higher wage-earning potential, these policy measures are also potentially effective at increasing labour supply.

37. Looking at the costs faced by employers, social contributions and payroll taxes add, on average, around $18 \%$ to the cost of employing minimum-wage workers. On an hourly basis, the resulting total cost of minimum-wage labour ranges from less than USD 2 (in Mexico, Poland, Slovak Republic and Turkey) to more than USD 11 (in France, Luxembourg and the Netherlands). Despite reductions in non-wage labour costs in several countries, there has been no convergence of minimum labour costs in recent years. 


\section{ANNEX A}

Table A1. Minimum wage levels used in the calculations

\begin{tabular}{|c|c|c|c|c|c|c|c|}
\hline & \multicolumn{5}{|c|}{ wage floor in national currency (1) } & \multicolumn{2}{|r|}{ applicability (2) } \\
\hline & hourly & daily & weekly & monthly & annual & age group & other \\
\hline Australia & & & 469 & & 24,378 & & \\
\hline Belgium & & & & 1,220 & 14,640 & $21+$ & private sector \\
\hline Canada & 7.30 & & & & 15,184 & & \\
\hline Czech Republic & 43.10 & & & & 89,648 & & \\
\hline France (3) & 7.82 & & & & 14,232 & & \\
\hline Greece (4) & & & & 675 & 8,100 & & single white collar workers, employed $<3$ years \\
\hline Hungary & & & & 57,000 & 684,000 & & \\
\hline Ireland & 7.43 & & & & 15,454 & $18+$ & \\
\hline Japan & 665.00 & & & & $1,383,200$ & & weighted average of rates across 47 relevant regions \\
\hline Korea & 2927.00 & & & & $7,105,440$ & & \\
\hline Luxembourg & 8.53 & & & & 17,712 & $18+$ & single individuals \\
\hline Mexico & & 45 & & & 16,513 & & "general" minimum wage: average across 3 regions \\
\hline Netherlands (4) & & & 315 & & 17,732 & $23+$ & \\
\hline New Zealand & 9.50 & & & & 19,760 & $18+$ & \\
\hline Poland & & & & 849 & 10,188 & & \\
\hline Portugal (4) & & & & 437 & 5,246 & $18+$ & non-agricultural workers \\
\hline Slovak Republic & 38.00 & & & & 79,040 & & \\
\hline Spain (4) & & & & 595 & 7,140 & $18+$ & \\
\hline Turkey & & 16 & & & 4,235 & $16+$ & \\
\hline United Kingdom & 4.95 & & & & 10,296 & $22+$ & \\
\hline United States & 5.15 & & & & 10,712 & $20+$ & federal minimum wage; higher minima in 17 states \\
\hline
\end{tabular}

1. Expressed in EUR for euro-zone countries. All minimum wage numbers relate to the relevant fiscal year (Australia: July 2004 to June 2005, New Zealand and UK: April 2005 to March 2006, calendar year in all other countries). 12-month averages are shown where the values have changed during the fiscal year. Where conversions to/from hourly wages were necessary, this has been done on the basis of 40 hours per week, except in Belgium (38), France (35), Korea (46), Poland (42 prior to 2001) and the UK (38).

2. Other minima can apply to other groups. For instance, minimum wages are often considerably lower for younger workers.

3. Salaire Minimum Interprofessionel de Croissance (SMIC). A higher minimum (Garanties Mensuelles de Rémunération, GMR) applied to employees affected by the mandatory reduction of working hours to 35 per week in order to keep their monthly wages unchanged. From 2005 onwards, the two minima are the same.

4. Adjusted to include holiday/Christmas allowances and 13th/14th monthly payments

Source: OECD Minimum Wage Database. 
Table A2. Average wage levels used in the calculations

\section{In national currency per year}

\begin{tabular}{|c|c|c|c|c|}
\hline & 2000 & 2005 & Type of Sample & Source \\
\hline Australia & 40218 & 51169 & $\begin{array}{l}\text { Quarterly survey of firms resulting in a representative sample of wage and } \\
\text { salary earners in each industry. }\end{array}$ & $\begin{array}{l}\text { Australian Bureau of Statistics "Average Weekly Earnings, Australia" and } \\
\text { "Labour Force, Australia" }\end{array}$ \\
\hline Austria & 29732 & 35128 & Annual Wage Tax Statistics & "Lohnsteuerstatistik" \\
\hline Belgium & 31644 & 36468 & $\begin{array}{l}\text { Data collected or estimated on the basis of an annual establishment survey and } \\
\text { social insurance registers of employees }\end{array}$ & $\begin{array}{l}\text { Statistics Division of the Ministry of Economy (Federal Public Service, } \\
\text { Economy, SMEs, Self-employed and Energy). }\end{array}$ \\
\hline Canada & 36764 & 39816 & Monthly survey of all firms & Statistics Canada, "Survey of Employment Payrolls and Hours" \\
\hline Czech Republic & 164327 & 220461 & Employer survey data & National Statistical Office \\
\hline Denmark & 281700 & 320300 & Danish Employers Confederation survey of earnings & $\begin{array}{l}\text { Annual Report Danish Employers Confederation (Dansk Arbejds } \\
\text { Giverforening) }\end{array}$ \\
\hline Finland & 27037 & 32671 & $\begin{array}{l}\text { (1) Finnish Employers Federation survey of hourly and monthly earnings; (2) } \\
\text { Survey for unorganized employers }\end{array}$ & "Wages Statistics" published by the Central Statistical Office \\
\hline France & 26731 & 30509 & Social insurance registers covering all employers. & INSEE, "Déclarations Annuelles des Données Sociales" (DADS) \\
\hline Germany & 37319 & 41691 & Survey carried out by the Federal Statistical Office & National Statistical Office \\
\hline Greece & 14721 & 20521 & Survey carried out by National Statistics Service and Social Security Institutions & $\begin{array}{l}\text { National Statistical Service Labour Statistics. Same source as for Eurostat } \\
\text { "Annual gross earnings" data. }\end{array}$ \\
\hline Hungary & 1084214 & 1818360 & Monthly surveys among enterprises with at least five employees. & Central Statistical Office \\
\hline Iceland & 2142000 & 2958000 & Monthly survey of earnings in the private sector market & Statistics Iceland \\
\hline Ireland & 22008 & 28994 & Quarterly surveys of industrial employment, earnings and hours worked & Central Statistics Office \\
\hline Italy & 19991 & 22662 & Quarterly indicators of wages in industry and services (OROS) & National Institute of Statistics \\
\hline Japan & 5026569 & 4964206 & $\begin{array}{l}\text { Basic survey on wage structure of all establishments with more than } 10 \\
\text { employees }\end{array}$ & Ministry of Health, Labour and Welfare, Annual Report \\
\hline Korea & 19217616 & 28840608 & Major Labour Statistics & Ministry of Labour \\
\hline Luxembourg & 35875 & 42135 & Monthly aggregated files of Social security services. & National Statistical Office and Social Security Services. \\
\hline Mexico & 47918 & 69465 & $\begin{array}{l}\text { Administrative data from the Mexican Social Security Institute (Instituto } \\
\text { Mexicano del Seguro Social (IMSS)) }\end{array}$ & $\begin{array}{l}\text { The National Minimum Wage Commission (Comisión Nacional de Salarios } \\
\text { Mínimos (CONASAMI)) }\end{array}$ \\
\hline Netherlands & 31300 & 38671 & Survey "Employment and Wages" & Central Bureau of Statistics, Statline \\
\hline New Zealand & 34923 & 40782 & $\begin{array}{l}\text { Quarterly employment survey is a sample survey of significant business with an } \\
\text { employment count of } 1 \text { or greater }\end{array}$ & Statistics New Zealand INFOS \\
\hline Norway & 298385 & 378782 & $\begin{array}{l}\text { Sample of enterprises based on published sector statistics for 3rd quarter - } \\
\text { except agriculture, forestry and fishing and private households }\end{array}$ & Statistics Norway Wage \\
\hline Poland & 24682 & 28563 & Estimates for different sectors & Monthly Statistical Bulletin \\
\hline Portugal & 10922 & 13397 & April and October survey of earnings carried out by the Ministry of Labour & Ministry of Labour \\
\hline Slovak Republic & 148173 & 216179 & Quarterly and annual statistical data & Slovak Statistical Office \\
\hline Spain & 17162 & 20439 & Quarterly survey of firms & $\begin{array}{l}\text { Instituto Nacional de Estadistica "Encuesta Trimestral de Coste Laboral" } \\
\text { (Labour Cost Survey) }\end{array}$ \\
\hline Sweden & 263581 & 316602 & September survey of Swedish employers & Statistics Sweden \\
\hline Switzerland & 65370 & 71638 & $\begin{array}{l}\text { Swiss Statistics Office. Personnes actives occupées selon la branche } \\
\text { économique }\end{array}$ & $\begin{array}{l}\text { La vie économique, SECO (Secrétariat d'Étata à l'économie) table B.8.1, } \\
\text { http://www.bfs.admin.ch/bfs/portal/fr/index/themen/03/04.html }\end{array}$ \\
\hline Turkey & 5545 & 15737 & Annual Manufacturing Industry Survey & Turkish Statistical Institute \\
\hline United Kingdom & 23607 & 29364 & $1 \%$ sample of PAYE earnings & $\begin{array}{l}\text { Office for National Statistics, Annual Survey of Hours and Earnings } \\
\text { (ASHE) }\end{array}$ \\
\hline United States & 27372 & 31096 & $\begin{array}{l}\text { Monthly surveys by Department of Labour on the basis of a questionnaire } \\
\text { covering more than } 40 \text { million non-agricultural wage and salary-workers }\end{array}$ & $\begin{array}{l}\text { Employment, Hours, and Earnings from the Current Employment Statistics } \\
\text { Survey }\end{array}$ \\
\hline
\end{tabular}

Note: EUR in euro-area countries.

Source: OECD (2007b). 
Table A3. Method used to calculate average earnings

\begin{tabular}{|c|c|c|c|c|c|c|c|c|c|c|c|}
\hline \multirow[b]{3}{*}{ Australia } & \multicolumn{5}{|c|}{ Items included and exluded from the earnings base } & \multicolumn{3}{|c|}{$\begin{array}{c}\text { Types of worker included and excluded } \\
\text { in the average wage measure }\end{array}$} & \multirow[b]{2}{*}{ Basic method of calculation used } & \multirow{2}{*}{$\begin{array}{l}\text { Income tax } \\
\text { year ends }\end{array}$} & \multirow{2}{*}{$\begin{array}{l}\text { Period to } \\
\text { which the } \\
\text { earnings } \\
\text { calculation } \\
\text { refers }\end{array}$} \\
\hline & Sickness ${ }^{1}$ & Vacations & Overtime & $\begin{array}{l}\text { Recurring } \\
\text { cash } \\
\text { payments }\end{array}$ & $\begin{array}{c}\text { Fringe } \\
\text { Benefits }\end{array}$ & $\begin{array}{l}\text { Supervisory } \\
\text { workers }\end{array}$ & $\begin{array}{l}\text { Managerial } \\
\text { workers }\end{array}$ & $\begin{array}{l}\text { part-time } \\
\text { workers }\end{array}$ & & & \\
\hline & Inc & Inc & Inc & Inc & Exc & Inc & Inc & Exc & Average weekly earnings x 52 & 30th June & Fiscal year \\
\hline Austria & Exc & Inc & Inc & Inc & $\begin{array}{c}\text { Taxable } \\
\text { value Inc }\end{array}$ & Inc & Inc & Exc & Average annual earnings & 31st December & Calendar year \\
\hline Belgium & Exc & Inc & Inc & Inc & Exc & Inc & Inc & Exc & $\begin{array}{l}\text { Monthly earnings in October × } 12 \text { (plus recurring } \\
\text { bonuses) }\end{array}$ & 31st December & Calendar year \\
\hline Canada & Exc & Inc & Inc & Inc & Exc & Inc & Inc & $\operatorname{Inc}^{6}$ & $\begin{array}{l}\text { Average weekly hours } x \text { average hourly earnings } \\
\text { Ave }\end{array}$ & 31st December & Calendar year \\
\hline Czech Republic & Exc & Inc & Inc & Inc & Exc & Inc & Inc & $\operatorname{Inc}^{6}$ & $\begin{array}{l}\text { Average monthly earnings } \times 12 \\
\text { Averate }\end{array}$ & 31st December & Calendar year \\
\hline Denmark & Exc & Inc & Exc & Inc & Exc & Inc & Inc & $\operatorname{Inc}^{6}$ & Hourly earnings x hours worked & 31st December & Calendar year \\
\hline Finland & Exc & Inc & Inc & Inc & Exc & Inc & $\operatorname{lnc}^{5}$ & Exc & $\begin{array}{l}\text { Hourly wages } x \text { usuall working time or (monthly } \\
\text { earnings x months) + vacation paymentst end of }\end{array}$ & 31st December & Calendar year \\
\hline France & Exc & Inc & Inc & Inc & Exc & Inc & Inc & Exc & 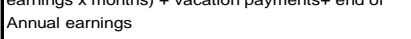 & 31st December & Calendar year \\
\hline Germany & Exc & Inc & Inc & Inc & Exc & Inc & Inc & Exc & Annual earnings & 31st December & Calendar year \\
\hline Greece & Exc & Inc & Inc & $\mathrm{Inc}^{2}$ & Inc & Inc & Inc & Exc & Hourly earnings $x$ hours worked & 31st December & Calendar year \\
\hline Hungary & Exc & Inc & Inc & Inc & Exc & Inc & $\operatorname{Inc}^{5}$ & Exc & Average monthly earnings $\times 12$ & 31st December & Calendar year \\
\hline Iceland & Exc & Inc & Inc & Inc & Exc & - & & - & Hourly earnings $x$ hours worked $\times 12$ & 31st December & Calendar year \\
\hline Ireland & Exc & Inc & Inc & Inc & Exc & Exc & Exc & Inc & $\begin{array}{l}\text { Average weekly earnings in each quarter for four } \\
\text { quarters } / 44^{\star} 52\end{array}$ & 31st December & Calendar year \\
\hline Italy & $\mathrm{Exc}^{3}$ & Inc & Inc & Inc & $\mathrm{Exc}^{4}$ & Inc & Exc & $\operatorname{Inc}^{6}$ & $\begin{array}{l}\text { a duarerise monthly earnings } \times 12 \\
\text { Average } 12\end{array}$ & 31st December & Calendar year \\
\hline Japan & Exc & Inc & Inc & Inc & Exc & Inc & Inc & Exc & Monthly earnings in June x 12 & 31st December & Calendar year \\
\hline Korea & Exc & Inc & Inc & Inc & Exc & Inc & Inc & Exc & Average monthly earnings x 12 & 31st December & Calendar year \\
\hline Luxembourg & Exc & Inc & Inc & Inc & Exc & Inc & Inc & Exc & 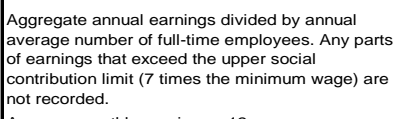 & 31st December & Calendar year \\
\hline Mexico & Exc & Inc & Exc & Inc & Exc & Inc & Inc & Exc & Average monthly earnings $\times 12$ & 31st December & Calendar year \\
\hline Netherlands & Exc & Inc & Exc & Inc & Exc & Inc & Inc & Exc & Annual gross earnings & 31st December & Calendar year \\
\hline New Zealand & Exc & Inc & Inc & Inc & Exc & Inc & $\operatorname{Inc}^{5}$ & $\operatorname{lnc}^{6}$ & Average weekly earnings in each quarter $x 13$ & 31st March & Tax year \\
\hline Norway & Exc & Exc & Inc & Inc & Exc & Inc & Inc & $\operatorname{Inc}^{6}$ & Annual wages + estimated overtime & 31st December & Calendar year \\
\hline Poland & Inc & Inc & Inc & Inc & Exc & Inc & Inc & $\operatorname{Inc}^{6}$ & Average monthly earnings x 12 & 31st December & Calendar year \\
\hline Portugal & Exc & Inc & Inc & Inc & Exc & - & - & . & Weighted monthly average $\times 12$ & 31st December & Calendar year \\
\hline Slovak Republic & Exc & Inc & Inc & Inc & Inc & Inc & Inc & Inc & Average monthly earnings $\times 12$ & 31st December & Calendar year \\
\hline Spain & Exc & Inc & Inc & Inc & Exc & Inc & Inc & Exc & Weighted monthly average x 12 & 31st December & Calendar year \\
\hline Sweden & Exc & Inc & Inc & Inc & $\begin{array}{l}\text { Actual value } \\
\text { Inc }\end{array}$ & Inc & Inc & $\operatorname{Inc}^{6}$ & $\begin{array}{l}\text { Average hourly earnings in September } x \text { hours } \\
\text { worked; and monthly earnings in September * } 12\end{array}$ & 31st December & Calendar year \\
\hline Switzerland & Exc & Inc & Inc & Inc & Exc & Inc & Inc & $\operatorname{Inc}^{6}$ & Monthly earnings x 12 & 31st December & Calendar year \\
\hline Turkey & Exc & Inc & Inc & Inc & $\begin{array}{c}\text { Actual value } \\
\text { inc }\end{array}$ & Exc & Exc & Inc & Average annual earnings & 31st December & Calendar year \\
\hline United Kingdom & Exc & Inc & Inc & Inc & Exc & Inc & Inc & Exc & Average gross annual earnings & 5th April & Fiscal year \\
\hline United States & Exc & Inc & Inc & $\operatorname{lnc}^{2}$ & Exc & Exc & Exc & $\operatorname{Inc}^{6}$ & Average weekly earnings x 52 & 31st December & Calendar year \\
\hline
\end{tabular}

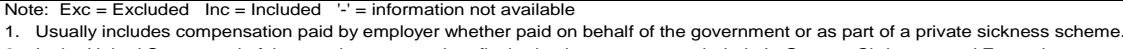

2. In the United States, end of the year bonuses and profit sharing bonuses are excluded. In Greece, Christmas and Easter bonuses are excluded.

three days of sick leave, while payments for the fourth day onwards

4. Partly: the (small) taxable part of fringe benefits is included.

5. Except for top management (Finland); except if income from profits exceeds $50 \%$ of total income (Hungary); except for proprietors (New Zealand) 


\section{BIBLIOGRAPHY}

Card, D. and A. Krueger (1995), Myth and Measurement: The New Economics of the Minimum Wage, Princeton University Press, Princeton, NJ.

Dolado, J., F. Kramarz, S. Machin, A. Manning, D. Margolis and C. Teulings (1996), “The economic impact of minimum wages in Europe”, Economic Policy, 23, pp. 318-72.

Falk, A., E. Fehr and C. Zehnder (forthcoming), “The behavioral effects of minimum wages”, Quarterly Journal of Economics. Also available as IZA Discussion Paper No. 1625, www.iza.org.

Immervoll, H., H. Kleven, C.T. Kreiner and E. Saez (2007), "Welfare reform in Europe: A microsimulation analysis", Economic Journal, 117 (516), pp. 1-44. Also available as OECD Social, Employment and Migration Working Paper No. 28, www.oecd.org/els/workingpapers.

Kertesi, G. and J. Köllõ (2003), “Fighting 'low equilibria’ by doubling the minimum wage? Hungary’s experiment“, IZA Discussion Paper No. 970, Institute for the Study of Labor, Bonn.

Neumark, D. and W. Wascher (2006), "Minimum wages and employment: A review of evidence from the new minimum wage research”, NBER Working Paper No. 12663, National Bureau of Economic Research, Cambridge, MA.

OECD (1998), Employment Outlook, OECD, Paris.

OECD (2004), Benefits and Wages. OECD Indicators, OECD, Paris.

OECD (2006), Employment Outlook, OECD, Paris.

OECD (2007a), Benefits and Wages. OECD Indicators, OECD, Paris, forthcoming.

OECD (2007b), Taxing Wages 2005-2006, OECD, Paris, forthcoming.

Stigler, G. J. (1946), “The economics of minimum wage legislation”, American Economic Review, 36, pp. 358-65. 